\title{
HYBRID SEED PRODUCTION IN DETERGENT- INDUCED MALE STERILE Helianthus annuus L.
}

\author{
Tripathi, S.M. and Singh, K.P.* \\ Department of Botany, R.B.S. College, Agra 282002, India \\ Received: November 15, 2007 \\ Accepted: December 05, 2008
}

\begin{abstract}
SUMMARY
Efficacy of a synthetic detergent "Surf Excel" as a potential male gametocide in Helianthus annuus was evaluated. Foliar applications of three concentrations of "Surf Excel" solution $(1.0,2.0$ and 3.0\% w/v) at different plant development stages caused reduction in plant height, pollen fertility, total yield/ plant, 100-seed weight and brought about early flowering in comparison with control plants. All treatments with "Surf Excel" solution caused elongation of the style in floral buds resulting in protrusion of receptive stigmas from the buds, which facilitated cross-pollination by honeybees. The plants sprayed once with 1\% "Surf Excel" solution exhibited protruded receptive stigmas and $99.87 \%$ pollen sterility along with insignificant reduction in total yield in comparison with control plants.
\end{abstract}

Key words: "Surf Excel" detergent, Helianthus annuus, floral changes, male sterility, seed production

\section{INTRODUCTION}

Chemicals that kill the male gametes, spores or organs and render the treated plant male sterile are known as "chemical-hybridizing agents" and the selective abolition of the male sex is termed "chemical male sterility" (Kaul, 1988). Chemical hybridizing agents facilitate hybrid seed production in the $F_{1}$ generation without backcrossing. Chemically induced male sterility obviates the use of genetic and gene-cytoplasmic male sterility. It does not require any special scheme, either for the development of male sterile and restorer genes, or for maintenance and increase of parental seeds (Gill, 1993). Chemical inhibitors of pollen development is not a familiar topic to the majority of scientists because these substances are found in patent literature and developed entirely within industrial research laboratories for hybrid seed production (Chakraborty and Devakumar, 2004, 2006; Wong

* Corresponding author: Phone: +91 562252 1642;

e-mail: singhkprbs@rediffmail.com; tripathismani@rediffmail.com 
et al., 1995). Therefore, they become highly expensive and enhance the cost of hybrid seed production, hence the emphasis, these days, is on the use of some new unconventional, cheap and widely used chemical hybridizing agents ( $\mathrm{Yu}$ et al., 2006). Synthetic detergents are quite capable to fulfill these requirements and may be a better alternative for costly conventional chemical hybridizing agents. Synthetic detergents like "Nirma" and "Surf Excel" has been used in wide range of crops (Singh, 1999; Singh, 2005). Keeping this in view, the efficacy of "Surf Excel" as a chemical hybridizing agent has been checked in Helianthus annuus and its effects on plant's height, leaves, days to first flowering, floral morphology, pollen fertility, total yield/plant and average seed weight were studied.

\section{MATERIALS AND METHODS}

The seeds of Helianthus annuus var. MSFH-17 were sown in a randomized row design at the Botanic garden, School of Life Sciences, Dr. Bhim Rao Ambedkar University, Khandari Agra, maintaining a uniform distance of about $25 \mathrm{~cm}$ between the plants and $45 \mathrm{~cm}$ between the rows. Aqueous solutions of different concentrations of "Surf Excel" solution (synthetic detergent powder, Hindustan Lever Ltd., Mumbai) $(1.0,2.0$ and $3.0 \% \mathrm{w} / \mathrm{v})$ were prepared in distilled water. Fifty plants were sprayed with this solution, about a week before the initiation of floral bud (Treatment- $T_{1}$ ) and another fifty plants were sprayed twice, first, a week before and second, five days after floral bud initiation (Treatment- $\mathrm{T}_{2}$ ). A group of fifty plants were sprayed with distilled water to serve as control group. Individual plants were sprayed with $15 \mathrm{ml}$ of the solution to the runoff. There were three replicates for each treatment. A row of plants of another variety namely GK-2002 was left untreated between two rows of treated plants. Plants of var. GK-2002 were served as male parent and provide pollen grains to the plants of var. MSFH-17 which act as female parent. Pollen fertility of treated and controlled plants was tested regularly throughout the flowering period, at an interval of twenty four hours with FCR test and Alexander's stain (1980). In vivo pollen germination in the pistils with raised stigmas was verified by the procedure after Shivanna and Rangaswamy (1992). The inflorescence of treated and untreated plants was bagged before making these tests. Data on plant height, days to first flowering, pollen fertility, total yield/plant and average seed weight from treated and controlled plants were collected and analyzed statistically by student's " $t$ " test.

\section{RESULTS}

Different concentrations of "Surf Excel" solution caused significant reduction in plant height (Table 1). This reduction in height was gradual and increases with the increase in concentration and number of treatments. Higher concentration of "Surf 
Excel" solution caused burning of leaves in treated plants. However, plants treated with lower concentration exhibited normal leaves.

All the treatments with different concentrations of "Surf Excel" solution brought about early flowering as compared to that in control plants (Table 1). The only exception was the group of plants sprayed twice with 3.0\% "Surf Excel" solution, which took the same number of days to first flowering (65 days) as in control group. On the other hand, plants sprayed once or twice with $1.0 \%$ "Surf Excel" solution took least number of days to flowering i.e. sixty two days only.

Table 1: Effects of "Surf Excel" on vegetative and reproductive parameters of Helianthus annuus $\mathrm{L}$.

\begin{tabular}{|c|c|c|c|c|c|c|c|c|c|c|c|}
\hline \multirow{2}{*}{$\begin{array}{l}\text { Chemical } \\
\text { hybridizing } \\
\text { agent }\end{array}$} & \multirow{2}{*}{$\begin{array}{l}\text { Concen- } \\
\text { tration } \\
\text { (\%) }\end{array}$} & \multicolumn{2}{|c|}{$\begin{array}{l}\text { Plant height } \\
\text { (cm) }\end{array}$} & \multicolumn{2}{|c|}{$\begin{array}{l}\text { Days to first } \\
\text { flowering }\end{array}$} & \multicolumn{4}{|c|}{$\begin{array}{c}\text { Pollen sterility Total yield/ plant } \\
\begin{array}{cc}(\%) & (\mathrm{g})\end{array}\end{array}$} & \multicolumn{2}{|c|}{$\begin{array}{l}100 \text {-seed } \\
\text { weight }(\mathrm{g})\end{array}$} \\
\hline & & $\mathrm{T}_{1}$ & $\mathrm{~T}_{2}$ & $\mathrm{~T}_{1}$ & $\mathrm{~T}_{2}$ & $\mathrm{~T}_{1}$ & $\mathrm{~T}_{2}$ & $\mathrm{~T}_{1}$ & $\mathrm{~T}_{2}$ & $T_{1}$ & $\mathrm{~T}_{2}$ \\
\hline \multirow{6}{*}{ "Surf Excel" } & \multirow{2}{*}{1.0} & $88.28^{*}$ & $79.30^{\star}$ & $62.0^{*}$ & $62.0^{*}$ & $99.87^{\star}$ & $100^{*}$ & $22.23^{*}$ & $18.30^{*}$ & 5.80 & $5.30^{*}$ \\
\hline & & \pm 2.81 & \pm 2.93 & \pm 2.87 & \pm 1.84 & \pm 0.88 & \pm 0.0 & \pm 1.880 & \pm 2.86 & \pm 0.15 & \pm 0.12 \\
\hline & \multirow{2}{*}{2.0} & $77.36^{\star}$ & $74.28 *$ & $63.0^{*}$ & 64.0 & $100^{*}$ & $100^{*}$ & $20.18^{*}$ & $17.06^{*}$ & $5.76^{\star}$ & $4.90 *$ \\
\hline & & \pm 2.79 & \pm 2.34 & \pm 1.79 & \pm 1.34 & \pm 0.0 & \pm 0.0 & \pm 2.29 & \pm 1.86 & \pm 0.14 & \pm 0.56 \\
\hline & \multirow{2}{*}{3.0} & $71.28^{\star}$ & $70.22^{\star}$ & 64.0 & 65.0 & $100^{*}$ & $100^{\star}$ & $14.86^{*}$ & $11.89^{*}$ & $4.20^{\star}$ & $3.90 *$ \\
\hline & & \pm 1.98 & \pm 2.13 & \pm 2.33 & \pm 0.84 & \pm 0.0 & \pm 0.0 & \pm 1.33 & \pm 3.20 & \pm 0.15 & \pm 0.26 \\
\hline \multicolumn{2}{|l|}{ Control } & 104.25 & \pm 4.14 & \multicolumn{2}{|c|}{$65.0 \pm 2.8$} & \multicolumn{2}{|c|}{$5.25 \pm 2.14$} & \multicolumn{2}{|c|}{$23.68 \pm 3.8$} & \multicolumn{2}{|c|}{$6.23 \pm 0.88$} \\
\hline
\end{tabular}

Different concentrations of "Surf Excel" solution brought about some interesting and unique changes in floral morphology. The disc florets are hermaphrodite, but protandrous (Figure la), and many are self-incompatible. Both stigma and stamens remain inside in mature floral buds of control plants (Figure lb). They are normally open 2 or more days. The first day, the anthers release their pollen in the anther tube, which is partly exerted from the corolla (Figure 1c). The pollen is collected freely by bees, along with the nectar at the flower base. The second day, the stigma pushes up through any pollen mass remaining, then its two lobes open outward, receptive to pollen but out of reach of its own pollen. The pollen grains of control plants exhibited well developed spines and also showed the well differentiated germ pore (Figure 1d). On the other hand, the situation was completely different in the floral buds of "Surf Excel" treated plants, here the style became elongated due to foliar application of 1,2 and 3\% "Surf Excel" so that the stigma protruded out at the bud stage (Figures 2a,b). Maximum elongation of the style was shown in plants treated with 3\% "Surf Excel" solution. About 1.0-2.0 mm long portion of style protruded out from the buds of treated plants and because of this stylar elongation, protrusion of stigmas from buds occurred two days before the anthesis (Figure $2 b$ ). However, this raised stigma was found to be receptive and allow germinating the pollen grains of other flowers brought about by bees (Figures 2c,d) and promoting 

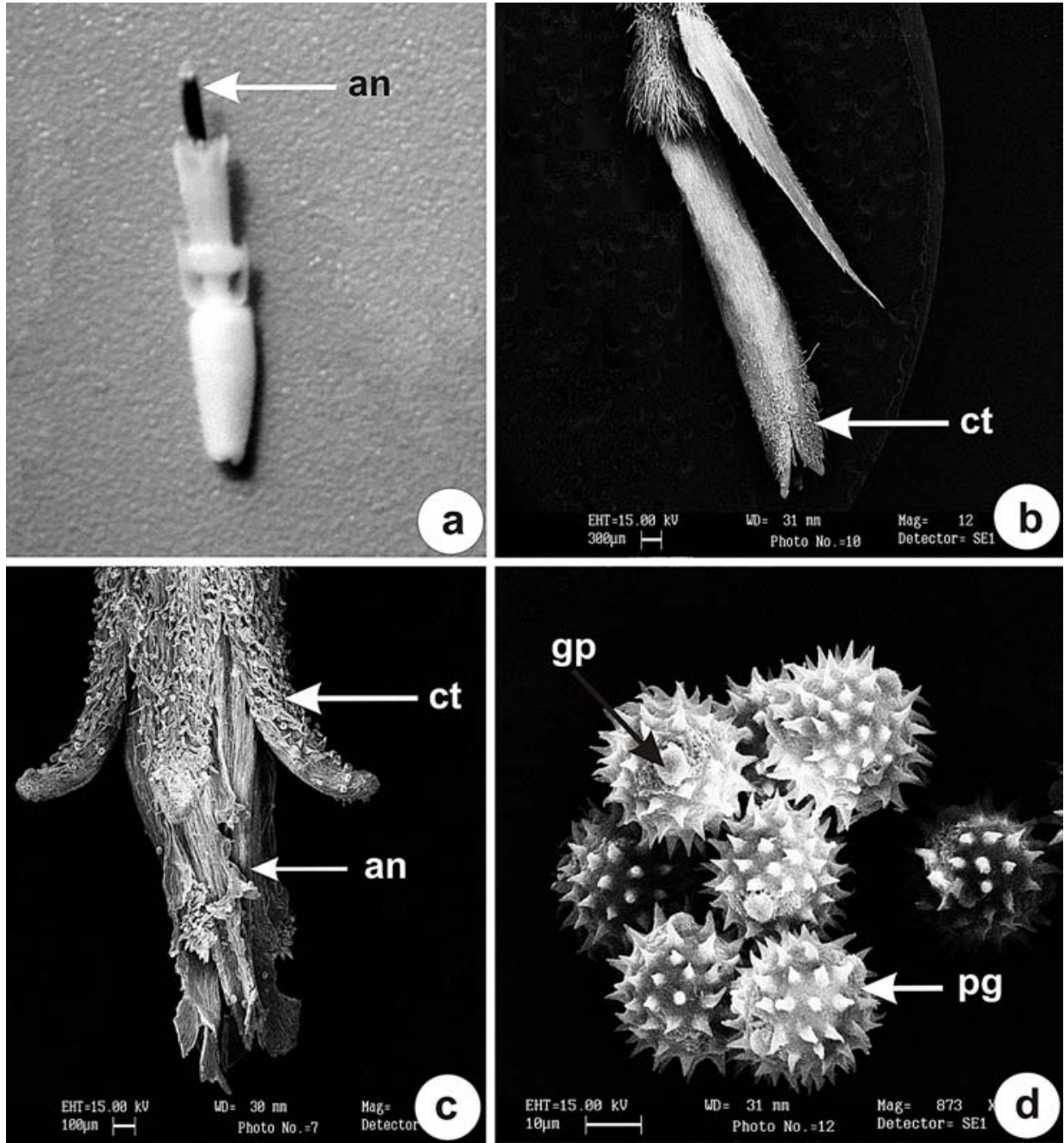

Figure 1: SEM micrographs of disc florets and pollen grains of male fertile control plants. a) Disc floret of control plant after anthesis showing only the presence of anthers (an). Note the stigma remaining inside the open floret.

b) SEM micrograph of disc floret in bud condition showing only corolla tube (ct). Both anthers and the stigma remain inside the bud.

c) SEM micrograph of disc floret showing emerging anthers (an) from corolla tube (ct). d) SEM micrograph of fertile pollen grains ( $\mathrm{pg}$ ) of control plant showing well developed germ pore (gp). 

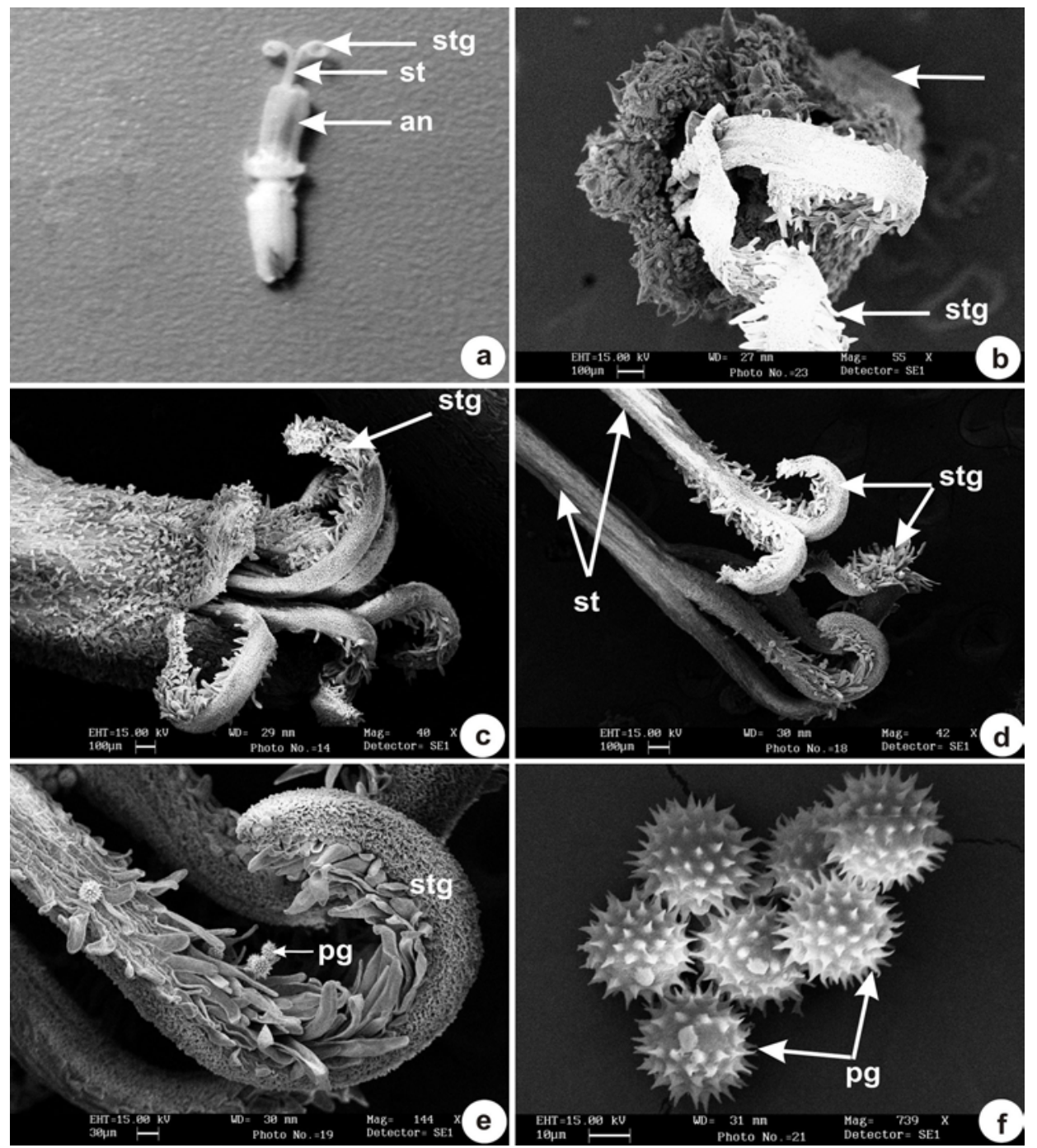

Figure 2: SEM micrographs of disc florets of 3\% "Surf Excel" treated plants showing the changes in floral morphology

a) Disc floret of 3\% "Surf Excel" treated plant. Note the presence of elongated style (st) with raised stigma (stg). Anthers (an) remain inside the corolla.

b) SEM micrograph of disc floret in bud state showing protruded stigma (stg) from enclosed corolla tube (ct).

c) Enclosed bud of "Surf Excel" treated plant showing many protruded stigmas (stg). Note the anthers remain inside the bud and protruded stigma promotes cross-pollination.

d) SEM micrograph of 2-3 styles (st) with bi-and trifid stigmas (stg) present in several single disc florets of treated plants.

e) Magnified view of Figure c showing stigmatic papillae (pp). Note the presence of pollen grains (pg) of different source on the stigma.

f) Pollen grains (pg) of 3\% "Surf Excel" treated plants showing poorly developed germ pore. 
cross breeding. Each raised stigma exhibited $85-90 \%$ pollen germination compared to $72-82 \%$ germination in control flowers. Disk florets of "Surf Excel" treated plants not only exhibited the protrusion of stigma but they also showed the polymorphism in the style and stigma. A limited number of disk florets possessed two or three styles and the stigma also became trifid (Figures 2c,e). Anthers in the plants treated with 3\% "Surf Excel" solution were indehiscent in nature. Pollen grains in "Surf Excel" treated plants were also exhibited spiny exine but the germ pore was not well differentiated as in control pollen grains (Figure $2 \mathrm{f}$ ).

All the concentrations and number of treatments of "Surf Excel" solution, except $1 \%$ solution (single spray), were found to be effective in inducing complete pollen sterility in Helianthus annuus (Table 1). Plants sprayed once with $1 \%$ "Surf Excel" showed $99.87 \%$ pollen sterility. The effect of pollen sterility in treated plants was found to be long lasting.

The 1\% "Surf Excel" solution was similar to control plants in terms of yield and other parameters, while all other concentrations exhibited significant deviation from the control group of plants. Plants treated once with $1 \%$ "Surf Excel" showed $22.23 \mathrm{~g}$ seed yield in comparison to $23.68 \mathrm{~g}$ seeds produced by control plants. Plants spray once with $2 \%$ "Surf Excel" also showed production of $20.18 \mathrm{~g}$ seeds along with $100 \%$ pollen sterility. There was also insignificant reduction in 100 seed weight in plants treated once with $1 \%$ "Surf Excel" (5.80 g) in comparison to control plants (6.23 g).

It is evident from the foregoing observations that single applications of land $2 \%$ aqueous "Surf Excel" solution not only induced almost complete pollen sterility in Helianthus annuus but also showed good yield.

\section{DISCUSSION}

CHAs treated plants may be different from untreated plants because of their phytotoxic effects. It was reported that CHAs could cause abnormal development of reproductive organs, withered leaves and flowers (Guan 1995; Liu et al., 1999). On the other hand, in present investigation changes, which occurred in floral morphology due to foliar application of detergent, were quite beneficial for the purpose of hybrid seed production. All the concentrations of "Surf Excel" solution caused enhancement in stylar length in buds of treated plants so that the stigma pushed out from the buds. Since the sterile anthers of same bud remain inside the bud and the raised receptive stigma was pollinated by the fertile pollen grains of other plants, therefore it favored the cross breeding. Bees also enhanced the chances of cross-pollination. Both the pollen and the nectar of sunflower are quite attractive to bees throughout the day (Bitkolov, 1961; Free, 1964). Nectar is secreted at the base of the floret, primarily during the pollen-producing stage of flowering but to some degree while stigmas are receptive. Extrafloral nectaries in the bracts and on the upper leaves of the plant are sometimes visited by honey bees, particularly in the 
afternoon (Free, 1964). These results were supported by the similar findings of stigmatic protrusion in detergent treated Brassica juncea reported by Singh and Chauhan (2003). The protrusion of the stigma is one of the significant features of male sterile plants (Su et al., 1997).

Now a days "Surf Excel" is being tried as a chemical hybridizing agent in large number of crops due to the presence of highest amount of phosphate $(30.2 \%)$ amongst all the leading detergents (Singh, 2005). The presence of high amount of phosphate and sodium carbonate in this detergent is mainly responsible for its ability to cause pollen sterility. Male sterility induced by synthetic detergents is caused by disturbances in cell division during the development of reproductive cells because detergents have mitotic inhibitory properties, which have been observed in Vigna radiata (Kumar and Kumar, 1990) and Allium cepa (Kumar, 1991). Although "Surf Excel" has successfully induced male sterility in number of plants, but its effect on yield component was disastrous in these plants at higher dosage (Singh, 2005). On the other hand Gangaprasad et al. (2004) have found adverse effect on normal growth and development of plants of Niger (Guizotia abyssinica) by the treatment of "Surf Excel" solution.

Pickett (1993) stated that, apart from inducing complete male sterility and low phytotoxicity, a good CHA should be economic and easy to apply and should not cause significant environmental or health risks. It was found that the utilization of "Surf Excel" fulfills some of the aforementioned requirements and hence we recommend its use as Chemical Hybridizing Agent in Helianthus annuus.

\section{ACKNOWLEDGEMENTS}

The first author is grateful to CSIR, New Delhi, for financial assistance in the form of JRF and SRF and to the Botany Department, School of Life Sciences, Dr. Bhim Rao Ambedkar University, Agra, for the facilities provided throughout the research period.

\section{REFERENCES}

Alexander, M.P., 1980. A versatile stain for pollen, fungi, yeast and bacteria. Stain Tech. 55: 13-18.

Bitkolov, R.S., 1961. Sunflower and Bees. Pchelovodstvo 38(5): 20-21.

Chakraborty, K. and Devakumar, C., 2004. Evaluation of chemical compounds for induction of male sterility in wheat (Triticum aestivum L.). Euphytica 16(3): 243-248.

Chakraborty, K. and Devakumar, C., 2006. Chemical hybridizing agents for chickpea (Cicer arietinum L.): leads from QSAR analysis of ethyl oxanilates and pyridones. Journal of Agricultural Food Chemistry 54(5): 1868-1873.

Free, J.B., 1964. The behaviour of honeybees on sunflowers (Helianthus annuus L.). Journal of Applied Ecology 1(1): 19-27.

Gill, H.S., 1993. Male sterility and its utilization in heterosis breeding. In: New Perspectives in Pollen and Spore Biology Advances in Pollen-Spore Research. Malik, C.P. (eds.), Today's and Tomorrow's Printers and Publishers New Delhi. pp. 69-77.

Gangaprasad, S., Sreedhar, R.V., Salimth, P.M. and Ravikumar, R.L., 2004. Induction of male sterility in Niger (Guizotia abyssinica Cass.). $4^{\text {th }}$ Int. Crop Sci. Cong. Brisbane. 
Guan, C.Y., 1995. Chemical induced male sterility and other ways of heterosis breeding. In: Breeding and Utilization of Hybrid Rapeseed, Fu, T.D. (eds.), Hubei Science and Technology Press, Wuhan, China. pp. 124-135.

Kaul, M.L.H., 1988. Male Sterility in Higher Plants. Monographs on Theor. and Appl. Genet. Springer Verlag Berlin, Heidelberg, New York. Vol. 10.

Kumar, M., 1991. Effect of synthetic detergents on interphase nuclei in Allium cepa L. Ind. J. Genet. \& Plant Breed. 51: 306-310.

Kumar, H. and Kumar, M., 1990. Effect of some detergent on germination and mitotic index in Vigna radiata. Annals of Agricultural Research 11: 316-138.

Liu, X.X., Dong, Z.S., Liu, C.S., Dong, J.G., Qiao, Y.Q., 1999. Studies of mechanism on male sterility in rape induced by chemical hybridization agent II. The effect of KMS-1 on fertility in oilseed rape. Chinese J. Oil Crop Science 20: 1-4.

Pickett, A.A., 1993. Hybrid wheat- results and problems, In: Advances in Plant Breeding. Robbelen, G., Weber, W.E. (eds.). Paul Parey Scientific Publishers, Berlin, Germany, 15: 1-259.

Singh, A.K., 1999. Male gametocidal effect of synthetic detergent in rice. Ind. J. Genet. \& Plant Breed. 59(3): 371-373.

Singh, V., 2005. Use of synthetic detergents as chemical hybridizing agents - a review. In: Plant Reproductive \& Molecular Biology. Chaturvedi, S.N. and Singh, K.P. (eds.), Aavishkar Publishers Distributors Jaipur. Festschrift 1: 88-95.

Singh, V. and Chauhan, S.V.S., 2003. Bud pollination and hybrid seed production in detergent induced male sterile plants of Brassica juncea (L.) Czern \& Coss. Plant Breed. 122(5): 421-425.

Su, Z.X., Qiu, U.S. and Zhao, T.Z., 1997. Relationship between stigma protrusion and sterility in sterile lines of rape (Brassica juncea L.). Oil Crops China 19: 5-7.

Wong, M., Blouet, A. and Guckert, A., 1995. Effectiveness of SC2053 as a chemical hybridizing agent for winter wheat. Importance of developmental stages and doses of application. Plant Growth Regul. 16(3): 243-248.

Yu, C., Hu, S., He, P., Sun, G., Zhang, C. and Yu, Y., 2006. Inducing male sterility in Brassica napus L. by a sulphonylurea herbicide, tribenuron-methyl. Plant Breed. 125(1): 61-63.

\title{
PRODUCCIÓN DE SEMILLA HÍBRIDA EN ANDROESTÉRILES DE Helianthus annuus L. INDUCIDOS POR DETERGENTE
}

\author{
RESUMEN
}

Se evaluó la eficacia del detergente sintético "Surf Excel" como gametocida masculino potencial. Aplicaciones foliares de soluciones de "Surf Excel" a tres concentraciones $(1.0,2.0$ y $3.0 \% \mathrm{w} / \mathrm{v})$ durante diferentes estadios del desarrollo causaron reducción de la altura de planta, fertilidad de polen, rendimiento total por planta, peso de 100 semillas y floración algo más temprana en comparación a las plantas control. Todos los tratamientos con soluciones de "Surf Excel" causaron elongación del estilo en primordios florales, resultando en una mayor separación de los estigmas receptivos de los primordios, lo que facilitó la polinización cruzada por abejas. Las plantas sobre las que se hizo una aplicación de solución de "Surf Excel" al 1\% exhibieron estigmas receptivos salientes y una esterilidad de polen del $99.87 \%$ junto con una reducción insignificante del rendimiento total en comparación con los controles. 


\title{
PRODUCTION DE GRAINE HYBRIDE DANS LES CONDITIONS OÙ LA STÉRILITÉ MÂLE CHEZ LE TOURNESOL (Helianthus annuus L.) EST SUSCITÉE AU MOYEN DE DETERGENT
}

\author{
RÉSUMÉ
}

L'efficacité d'un détergent synthétique "Surf Excel" comme gamétocide potentiel chez Helianthus annuus a été évaluée. Des applications foliaires à trois concentrations (1.0, 2.0 and 3.0\% w/v) de "Surf Excel" en solution à différents stades de développement a entraîné une reduction de la hauteur de la plante, de la fertilité du pollen, du rendement total de la plante, tu poids de 100 grains, et s'est traduit par une floraison plus précoce en comparaison avec les plantes témoins. Tous les traitements avec la solution de "Surf Excel" ont entraîné une élongation du style dans les boutons floraux résultant en la protubérance du stigmate à l'extérieur des boutons floraux, ce qui a facilité la fécondation croisée âr les abeilles. Les plantes traitées une fois avec la solution de "Surf Excel" à $1 \%$ ont montrer des stigmates réceptifs protubérants et une stérilité pollinique de $99.87 \%$, ainsi qu'une réduction non significative de la productivité en comparaison avec les témoins. 
